\title{
Tylopilusin C, a new diphenolic compound from the fruiting bodies of Tylopilus eximinus
}

\author{
Takashi Fukuda and Hiroshi Tomoda
}

The Journal of Antibiotics (2013) 66, 355-357; doi:10.1038/ja.2013.23; published online 24 April 2013

Keywords: diphenolic compound; tylopilusins; Tylopilus eximinus

Fungi are known as producers of many important bioactive compounds, including clinical medicines and research reagents. Certain fruit bodies of fungi are used as traditional medicines especially in Asian area. ${ }^{1-3}$ During our screening for new metabolites from fungi, four new diphenolic compounds, named ( \pm )-tylopilusin A and $( \pm)$ tylopilusin B, were isolated from the fruiting bodies of Tylopilus eximinus. ${ }^{4}$ Continuing precise analysis of the metabolites from the fungus, one new diphenolic congener, tylopilusin C (1), was isolated (Figure 1). In this study, we describe the isolation, structural elucidation and biological activity of $\mathbf{1}$ in brief.

The fungus T. eximius was collected at Nagano, Japan in 2010. The fresh fruit body $(300 \mathrm{~g})$ was extracted with methanol $(500 \mathrm{ml})$ for 2 months. After this extract being evaporated to aqueous solution, the residue was partitioned between water and EtOAc (ethyl ethanoate) to yield the tylopilusin mixture $(1.1 \mathrm{~g})$ after evaporation of the EtOAc fraction. The crude extract was dissolved in a small volume of chloroform, applied on a silica gel column $\left(22 \mathrm{~g}, 28 \times 14 \mathrm{~cm}^{2}\right.$,
0.04-0.063 mm, MERCK, Darmstadt, Germany) and eluted stepwise with $100 \%$ chloroform, 20:1, 10:1, 5:1 and 1:1 (v/v) chloroformmethanol and $100 \%$ methanol $(200 \mathrm{ml}$ each). Tylopilusin C was observed in the fraction eluted with 1:1 chloroform-methanol. This fraction was further purified by reversed-phase C18 HPLC $\left(20 \times 250 \mathrm{~mm}^{2}\right.$, PEGASIL ODS, Senshu Scientific Co., Tokyo, Japan $)$ under the following conditions; solvent, a 30-min linear gradient from $20-40 \%$ acetonitril in $0.05 \%$ trifluoroacetic acid; a flow rate of $8.0 \mathrm{mlmin}^{-1}$; UV detection at $340 \mathrm{~nm}$. Under these conditions, tylopilusin $\mathrm{C}$ was eluted as a peak with a retention time of $20.1 \mathrm{~min}$. This fraction was collected and concentrated to yield pure tylopilusin C $(6.0 \mathrm{mg})$ as a pale yellow solid.

The structure of 1 was mainly elucidated by analysis of NMR spectra, including 2D NMR. The molecular formula for $\mathbf{1}$ was established as $\mathrm{C}_{18} \mathrm{H}_{12} \mathrm{O}_{7}\left([\mathrm{M}+\mathrm{H}]^{+} \mathrm{m} / z\right.$ 341.0659) on the basis of high resolution ESI-MS measurement, indicating that 1 contained 13 degrees of unsaturation. (Table 1) The IR spectrum of 1 showed

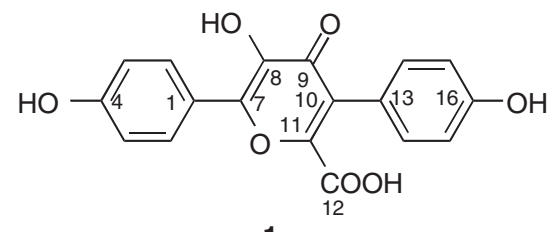

1

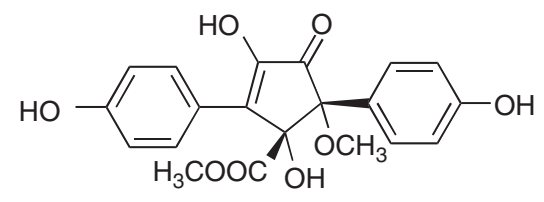

Tylopilusin A1<smiles>COC(=O)c1oc(-c2ccc(OC)cc2)c(OC)c(=O)c1-c1ccc(OC)cc1</smiles>

2<smiles>COC(=O)[C@]1(O)C(c2ccc(O)cc2)=C(O)C(=O)[C@]1(O)c1ccc(O)cc1</smiles>

Tylopilusin B1

Figure 1 Structures of tylopilusin C (1), tetramethyltylopilusin C (2), tylopilusins A1 and B1. 
Table 1 Physico-chemical properties of tylopilusin C

\begin{tabular}{lc}
\hline & Tylopilusin $\mathrm{C}$ \\
\hline Appearance & Pale yellow solid \\
Molecular formula & $\mathrm{C}_{18} \mathrm{H}_{12} \mathrm{O}_{7}$ \\
Molecular weight & 340 \\
$\mathrm{HR}-\mathrm{ESI}-\mathrm{MS} \mathrm{m} / \mathrm{z}$ & $(\mathrm{M}+\mathrm{H})+$ \\
Calcd & $341.0661\left(\mathrm{for} \mathrm{C}_{18} \mathrm{H}_{13} \mathrm{O}_{7}\right)$ \\
Found & 341.0659 \\
$\mathrm{UV} \lambda_{\max }^{\mathrm{MeOH}} \mathrm{nm}(\varepsilon)$ & $336(2,600), 278(4,200)$, \\
$\mathrm{IR} v_{\max }^{\mathrm{KBr}} \mathrm{cm}^{-1}$ & $247(5,200)$ \\
\hline
\end{tabular}

Table 2 NMR spectroscopic data in DMSO- $d_{6}$ for tylopilusin C

\begin{tabular}{|c|c|c|c|}
\hline Position & $\delta_{H^{\mathrm{a}}}$ & $\delta_{C}{ }^{\mathrm{b}}$ & $H M B C$ \\
\hline 1 & & 121.4 & \\
\hline 2 & 7.93, d $(J=9.0)$ & 128.8 & $C-4,6,7$ \\
\hline 3 & 6.92 , d $(J=9.0)$ & 115.6 & C- $1,4,5$ \\
\hline 4 & & 159.0 & \\
\hline 5 & $6.92, \mathrm{~d}(J=9.0)$ & 115.6 & $C-1,3,4$ \\
\hline 6 & 7.93 , d $(J=9.0)$ & 128.8 & $C-2,4,7$ \\
\hline 7 & & 145.0 & \\
\hline 8 & & 141.7 & \\
\hline 9 & & 173.3 & \\
\hline 10 & & 125.5 & \\
\hline 11 & & 159.1 & \\
\hline 12 & & 162.2 & \\
\hline 13 & & 121.7 & \\
\hline 14 & 7.06, d $(J=9.0)$ & 131.0 & C-10, 16, 18 \\
\hline 15 & $6.75, \mathrm{~d}(J=9.0)$ & 114.0 & $\mathrm{C}-13,16,17$ \\
\hline 16 & & 157.3 & \\
\hline 17 & $6.75, \mathrm{~d}(J=9.0)$ & 114.7 & $\mathrm{C}-13,15,16$ \\
\hline 18 & $7.06, \mathrm{~d}(J=9.0)$ & 131.0 & $\mathrm{C}-10,14,16$ \\
\hline $4-\mathrm{OH}$ & 10.07, s & & $C-3,4,5$ \\
\hline $8-\mathrm{OH}$ & - & & \\
\hline $12-\mathrm{OH}$ & - & & \\
\hline $16-\mathrm{OH}$ & $9.50, \mathrm{~s}$ & & $\mathrm{C} 15,16,17$ \\
\hline
\end{tabular}

Abbreviation: DMSO- $d_{6}$, dimethyl sulfoxide-D6.

${ }^{a}$ Chemical shifts are shown with reference to DMSO- $d_{6}$ as $\delta 2.49$.

${ }^{6}$ Chemical shifts are shown with reference to DMSO- $d_{6}$ as $\delta 39.7$. characteristic absorption at 3259 and $1685 \mathrm{~cm}^{-1}$, suggesting the presence of a carbonic acid moiety. The ${ }^{1} \mathrm{H}$ NMR spectrum of 1 (in DMSO- $d_{6}$ (dimethyl sulfoxide-D6)) showed four types of aromatic methine signals. (Table 2) Analysis of the ${ }^{1} \mathrm{H}$ NMR data using decoupling methods suggested two types of 1,4-disubstituted benzene rings. The ${ }^{13} \mathrm{C}$ NMR spectrum (in DMSO- $d_{6}$ ) showed 18 resolved signals, which were classified into $8 s p^{2}$ methine carbons and 10 quaternary carbons, including 2 carbonyl carbons (C-9 and C-12) and 5 oxygenated $s p^{2}$ carbons (C-4, C-7, C-8, C-11 and C-16) (Table 2). Among them, C-1 to C-6 and C-13 to C-18 were identified as 1, 4-disubstituted benzene ring carbons. Furthermore, the chemical shifts of C-7 ( $\delta$ 145.0), C-8 ( $\delta$ 141.7), C-9 ( $\delta$ 173.3), C-10 $(\delta 125.5)$ and $\mathrm{C}-11(\delta 159.1)$ suggested that a 3-hydroxy-4-pyranone ring should exist. ${ }^{5,6}$ In additional HMBC NMR experiment, the cross peaks from $2-\mathrm{H}$ and $6-\mathrm{H}(\delta 7.93)$ to $\mathrm{C}-7$ indicated that one benzene is linked at $\mathrm{C}-7$ of the pyranone ring. Furthermore, correlations from $14-\mathrm{H}$ and $18-\mathrm{H}(\delta 7.06)$ to $\mathrm{C}-10$ allowed the other benzene and the pyranone functionalities to be joined at $\mathrm{C}-10$ as shown in Figure 1. Taking into consideration the molecular formula and the IR data, a carbonyl acid moiety was connected at $\mathrm{C}-11$. Based on all the data, the total structure of 1 was elucidated as shown in Figure 1. Unfortunately, signals of $8-\mathrm{OH}$ and $12-\mathrm{OH}$ were not obserbed in ${ }^{1} \mathrm{H}$ NMR experiments. To confirm the structure, 1 was methylated with trimethylsilyl diazomethane, ${ }^{7}$ and the derivative 2 was analyzed by HI-ESI-MS measurements. (Methylation of tylopilusin C; Tylopilusin C (1.8 mg) was disolved in $\mathrm{MeOH}(200 \mu \mathrm{l})$ and benzene $(800 \mu \mathrm{l})$ and trimethylsilyl diazomethane was added $(500 \mu \mathrm{l}$, Tokyo Chemical Industry Co. Ltd., Tokyo, Japan) at $25^{\circ} \mathrm{C}$ for $30 \mathrm{~min}$. The reaction mixture was evaporated in vacuo to obtain the products $(1.8 \mathrm{mg})$. The products were purified by reversed-phase C-18 HPLC $\left(10 \times 250 \mathrm{~mm}^{2}\right.$, PEGASIL ODS), a $70 \%$ acetonitril in $0.05 \%$ trifluoroacetic acid, at a flow rate $2.5 \mathrm{ml} \mathrm{min}^{-1}$ with $\mathrm{UV}$ detection at $340 \mathrm{~nm}$. Under this condition, tetramethyltylopilusin C (2) was eluted as a peak with a<smiles>NC(Cc1ccc(O)cc1)C(=O)O</smiles>

$\mathrm{x} 2$

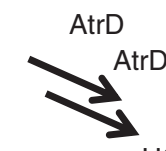<smiles>COc1ccc(C2=C(O)C(=O)C(c3ccc(O)cc3)=C(O)C2=O)cc1</smiles><smiles>O=C(O)C(C(=O)O)=C(O)C(=O)/C=C(\O)c1ccc(O)cc1</smiles>

Atromentin<smiles>O=C(O)c1oc(-c2ccc(O)cc2)c(O)c(=O)c1-c1ccc(O)cc1</smiles><smiles>C1CCC1</smiles><smiles>CCCC1(C)C(c2ccc(O)cc2)=C(O)C(=O)[C@]1(O)c1ccc(O)cc1</smiles>

Tylopilusin A1

Tylopilusin C

Scheme 1 Proposed biosynthetic pathway of tylopilusins. 
retention time of $13.2 \mathrm{~min}$. This peak was collected and concentrated to yield $1.0 \mathrm{mg}$ as pale yellow solid.) (Tetramethyltylopilusin C (2): Pale yellow solid; ${ }^{1} \mathrm{H}$ NMR $\left(600 \mathrm{MHz}, \mathrm{CDCl}_{3}\right) \delta_{\mathrm{H}} 8.07(2 \mathrm{H}, \mathrm{d}$, $J=9.0 \mathrm{~Hz}), 7.24(2 \mathrm{H}, \mathrm{d}, J=9.0 \mathrm{~Hz}), 7.02(2 \mathrm{H}, \mathrm{d}, J=9.0 \mathrm{~Hz}), 6.96$ $(2 \mathrm{H}, \mathrm{d}, J=9.0 \mathrm{~Hz}), 3.92(3 \mathrm{H}, \mathrm{s}), 3.89(3 \mathrm{H}, \mathrm{s}), 3.84(3 \mathrm{H}, \mathrm{s})$ and 3.75 $(3 \mathrm{H}, \mathrm{s})$; HR-ESI-MS $[\mathrm{M}+\mathrm{Na}]^{+} \mathrm{m} / z 419.11098\left(\mathrm{C}_{22} \mathrm{H}_{20} \mathrm{O}_{7} \mathrm{Na}\right.$, calcd 419.1107).) The molecular formula of 2 was established as $\mathrm{C}_{22} \mathrm{H}_{20} \mathrm{O}_{7}$, indicating that four methyl residues were incorporated into $\mathbf{1}$. Furthermore, four methoxyl methyl signals ( $\delta$ 3.92, 3.89, 3.84 and 3.75) were observed in ${ }^{1} \mathrm{H}$ NMR experiments. Thus, the structure of the derivative was elucidated as 2 , supporting the structure of 1 .

The plausible biosynthetic pathway is proposed in Scheme 1. The biosynthetic precursor atromentin, ${ }^{8}$ which was isolated from the same broth of this strain, is biosynthesized from two L-tylosines by enzymes AtrA and AtrD. ${ }^{9}$ Next, atromentin can be opened in the central ring (I) and re-cyclized to afford tylopilusin A and/or tylopilusin C type ring systems by enzymatic reactions.

The biological activity of 1 was investigated using in-house assay system. By our routine antimicrobial assay systems, ${ }^{10} \mathbf{1}(20 \mu \mathrm{g}$ per 6-mm disk) showed no antimicrobial activity against Gram-positive and -negative bacteria, fungi and yeasts ${ }^{10}$ tested. However, 1 was found to inhibit the yellow pigment production by methicillinresistant Staphylococuss aureus (MRSA) with a white zone $(8 \mathrm{~mm})$ at $10 \mu \mathrm{g}$ per $6-\mathrm{mm}$ disk. ${ }^{11}$ These data suggested that 1 might selectively inhibit staphyloxanthin production by MRSA without any effect on the growth of MRSA.

\section{ACKNOWLEDGEMENTS}

We thank Ms Noriko Sato and Dr Kenichiro Nagai (School of Pharmaceutical Sciences, Kitasato University, Tokyo, Japan) for measurements of NMR spectra and MS data. This work was supported by Takeda Science Foundation and Kitasato University research grant for young researchers (to TF).

1 Man, S., Gao, W., Wei, C. \& Liu, C. Anticancer drug from traditional toxic Chinese medicines. Phytother. Res. 26, 1449-1465 (2012).

2 Zheng, P. et al. Genome sequence of the insect pathogenic fungus Cordyceps militaris, a valued traditional chinese medicine. Genome Biol. 12, R116 (2011).

3 Ferreira, I. C., Vaz, J. A., Vasconcelos, M. H. \& Martins, A. Compounds from wild mushrooms with antitumor potential. Anticancer Agents Med. Chem. 10, 424-436 (2010).

4 Fukuda, T., Nagai, K. \& Tomoda, H. ( \pm )-Tylopilusins, diphenolic metabolites from the fruiting bodies of Tylopilus eximius. J. Nat. Prod. 75, 2228-2231 (2012).

5 Raku, T. \& Tokiwa, Y. Regioselective synthesis of kojic acid esters by Bacillus subtilis protease. Biotechnol. Lett. 25, 969-974 (2003).

6 Volynkin, V. A., Pachuev, A. V., Pirogova, A. N., Panyushkin, V. T. \& Shurygin, A. Y. An NMR study of comenic acid and its salts with $\mathrm{Li}^{+}$and $\mathrm{Na}^{+}$in aqueous solution and solid state. J. Struct. Chem. 52, 892-896 (2011).

7 Aoyama, T. \& Shioiri, T. New methods and reagents in organic synthesis. 8. Trimethylsilyldiazomethane. A new, stable, and safe reagent for the classical arndteistert synthesis. Tetrahedron Lett. 21, 4461-4462 (1980).

8 Khanna, J. M., Malone, M. H., Euler, K. L. \& Brady, L. R. Atromentin. Anticoagulant from Hydnellum diabolus. J. Pharm. Sci. 54, 1016-1020 (1965).

9 Schneider, P., Bouhired, S. \& Hoffmeister, D. Characterization of the atromentin biosynthesis genes and enzymes in the homobasidiomycete Tapinella panuoides. Fungal Genet. Biol. 45, 1487-1496 (2008).

10 Iwatsuki, M. et al. Lariatins, novel anti-mycobacterial peptides with a lasso structure, produced by Rhodococcus jostii K01-B0171. J. Antibiot. 60, 357-363 (2007).

11 Sakai, K. et al. Method of search for microbial inhibitors of staphyloxanthin production by MRSA. Biol. Pharm. Bull. 35, 48-53 (2012). 